\title{
NILAI-NILAI ISLAMI DALAM NOVEL API TAUHID KARYA HABIBURRAHMAN EL SHIRAZY: KAJIAN SOSIOLOGI SASTRA
}

\author{
Suharso \\ SDN Guci, Kecamatan Karanggeneng, Kab. Lamongan \\ HP 081615080854; pos-el suharsowahyu9@gmail.com;
}

\begin{abstract}
Abstrak: Tujuan penelitian ini adalah untuk mendeskripsikan nilai-nilai akidah,ibadah,dan akhlak yang terkandung dalam novel Api Tauhid karya Habiburrahman El-Shirazy. Penelitian ini merupakan jenis penelitian kualitatif, yaitu sebuah penelitian yang tidak menggunakan perhitungan angka-angka.Pada penelitian ini peneliti menggunakan penelitian kepustakaan (library research).Dalam pengumpulan data menggunakan teknik telaah dokumen atau biasa disebut dengan analisis dokumentasi.Analisis data dalam penelitian ini melalui tiga tahap, antara lain: reduksi data, penyajian data, dan penarikan kesimpulan. Nilai-nilai Islami yang terkandung dalam novel Api Tauhid antara lain: nilai-nilai akidah yang meliputi penanaman nilai keimanan, iman kepada Allah, iman kepada takdir Allah, dan iman kepada hari akhir.Nilai-nilai ibadah meliputi shalat tepat waktu, menjaga diri dari perbuatan maksiat, berdzikir, shalawat, dan berdakwah. Nilai-nilai akhlak meliputi hormat kepada orang tua, hormat kepada ahli ilmu, hormat kepada pemerintah, rendah diri, sopan santun, dan jujur.
\end{abstract}

Kata kunci: nilai Islami, nilai akidah, nilai ibadah, nilai akhlak

\begin{abstract}
The purpose of this study is to describe the values of faith, worship, and morals contained in the novel Api Tauhid by Habiburrahman El-Shirazy. This research is a type of qualitative research, which is a study that does not use calculation of numbers. In this study researchers used library research. In collecting data using document review techniques or commonly called documentation analysis. Data analysis in this study through three stages, including: data reduction, data presentation, and conclusion. Islamic values contained in the novel Api Tauhid include: the values of the faith which include planting the value of faith, faith in God, faith in the destiny of Allah, and faith in the last day. The values of worship include prayer on time, guarding against immoral acts, recitation, prayer, and preaching. Moral values include respect for parents, respect for experts, respect for the government, inferiority, courtesy, and honesty.
\end{abstract}

Keywords: Islamic values, faith values, worship values, moral values

\section{PENDAHULUAN}

Sastra dapat berfungsi sebagai karya seni yang bisa digunakan sebagai sarana menghibur diri pembaca.Hai ini sesuai dengan pendapat Warren (dalam
Nurgiyantoro, 2007: 3) yang menyatakan bahwa membaca sebuah karya sastra fiksi berarti menikmati cerita dan menghibur diri untuk memperoleh kepuasan batin.Karya sastra merupakan karya 
imajinatif yang dipandang lebih luas pengertiannya daripada karya fiksi.Novel sebagai salah satu bentuk karya sastra dapat dengan bebas berbicara tentang kehidupan yang dialami oleh manusia dengan berbagai peraturan dan normanorma dalam interaksinya dengan lingkungan sehingga dalam karya sastra (novel) terdapat makna tertentu tentang kehidupan.

Ada beberapa masalah yang muncul saat membahas masalah karya sastra.Nurgiyantoro (2007: 31-32) mengemukakan bahwa salah satu penyebab sulitnya pembaca dalam menafsirkan karya sastra, yaitu dikarenakan novel merupakan sebuah struktur yang kompleks, unik, serta mengungkapkan sesuatu secara tidak langsung.Oleh karena itu, perlu dilakukan suatu bukti-bukti hasil kerja analisis.Pengkajian terhadap karya fiksi, berarti penelaah, penyelidikan, atau mengkaji, menelaah, menyelidiki karya fiksi tersebut.

Suatu karya sastra dianggap berhasil bila mempunyai nilai.Nilai-nilai itu adalah pertama nilai hidonik artinya sastra memberi kesenangan langsung kepada pembacanya.Kedua nilai artistik yaitu memanifestasikan keterampilan seseorang.Ketiga kultural yaitu suatu karya sastra mengandung suatu hubungan antara peradaban atau masyarakat dengan kebudayaan. Keempat nilai etika ,pendidikan dan agama. Dalam karya sastra mengandung ajaran-ajaran yang ada sangkut pautnya dengan etika pendidikan dan agama.

Sastra merupakan media komunikasi yang menyajikan keindahan memberikan makna terhadap kehidupan atau pemberian pelepasan kedunia imajinasi (Budianta,2003:3). Sastra berkaitan erat dengan semua aspek manusia dan alam keseluruhanya. Setiap karya sastra selalu menghadirkan sesuatu yang kerap menyajikan banyak hal yang apabila yang apabila dihayati benar-benar akan semakin menambah pengetahuan orang yang menghayati (Purba,2010:3).

Novel Api Tauhid karya Habiburrahman El-Shirazy adalah novel roman dan sejarah. Novel roman yang bercerita seputar perjuangan anak muda asal Lumajang, Jawa Timur, yang bernama Fahmi.Ia dan beberapa rekannya seperti Ali, Hamza, dan Subki, menuntut ilmu di Universitas Islam Madinah.Dalam perjalanannya, Fahmi harus menghadapi situasi yang cukup pelik, dalam urusan rumah tangga.Fahmi pun galau. Semua persoalan yang dialaminya itu, tak pernah ia ungkapkan dengan teman-temannya.

Kegalauannya itu ia tumpahkan dengan cara beri'tikaf di Masjid Nabawi, Madinah, selama 40 hari untuk mengkhatamkan hafalan Al-Qur'an sebanyak 40 kali. Sayangnya, upayanya itu hanya mampu dijalani selama 12 hari.Memasuki hari-hari berikutnya, Fahmi pingsan.Ia tak sadarkan diri, hingga harus dibawa ke rumah sakit.Sahabat-sahabatnya khawatir dengan kondisinya yang pemurung dan tidak seceria dulu.

Melihat kondisi Fahmi yang murung seperti itu Hamza, temannya yang berasal dari Turki, mengajak Fahmi untuk berlibur ke Turki.Hamza berharap, Fahmi bisa melupakan masa-masa galaunya selama di Turki nanti.Untuk itulah, Hamza mengajak Fahmi menelusuri jejak perjuangan Said Nursi, seorang ulama besar asal Desa Nurs.Ulama terkemuka ini, dikenal memiliki reputasi yang mengagumkan.Syaikh Said Nursi, sudah mampu menghafal 80 kitab karya ulama klasik pada saat usianya baru menginjak 15 tahun.Tak hanya itu, Said Nursi hanya membutuhkan waktu dua hari untuk menghafal Al-Qur`an. Sungguh 
mengagumkan. Karena kemampuannya itu, sang guru, Muhammed Emin Efendi memberinya julukan "Badiuzzaman" yang berarti Keajaiban Zaman.

Novel Api Tauhid mempunyai nilai lebih dari sekadar novel percintaan remaja saat ini. Ini bukan hanya novel sejarah yang menyadarkan, tapi juga novel cinta yang menggetarkan.Sifat dan penokohan dalam novel tersebut sangat cocok dijadikan contoh bagi kehidupan remaja masa kini, tokoh utamanya sangat kental dengan nilai-nilai islami, seperti itikaf dan mengkhatamkan Alquran sebanyak empat puluh kali.

Nilai-nilai islami dan pesan-pesan moral yang kental yang diperankan tokoh-tokoh dalam novel itulah menjadikan sangat menarik untuk diteliti.

Berdasarkan uraian di atas, dapat dikembangkan secara rinci alasan diadakan penelitian ini sebagai berikut : Pertama Novel Api Tauhid sangat menarik karena di samping bercerita tentang kisah percintaan remaja juga mengisahkan sejarah tokoh ulama besar dan berpengaruh di Turki bernama Syaikh Badiuzzaman Said Nursi; Keduapeneliti berpendapat bahwa novel Api Tauhid karya Habiburrahman ElShirazy ini sarat dengan muatan nilainilaiislamidan nilai-nilai moral yang berhubungan dengan akidah, ibadah dan akhlak.

Dalam penelitian ini, peneliti menggunakan pendekatan Sosiologi Sastra untuk mengkaji unsur pesan atau amanah berupa nilai-nilai islami yang dialami oleh tokoh utama Syaikh Badiuzzaman Said Nursi dalam novel Api Tauhid karya Habiburrahman ElShirazy. Oleh karena itu, dalam penelitian ini dipilih judul Nilai-Nilai Islami dalam Novel Api Tauhid Karya Habiburrahman El Shirazy : Kajian Sosiologi Sastra.

\section{METODE PENELITIAN}

Penelitian Nilai-nilai Islami dalam Novel Api Tauhid Karya Habiburrahman El Shirazy : Kajian Sosiologi Sastra ini merupakan jenis penelitian kualitatif, yaitu sebuah penelitian yang tidak menggunakan perhitungan angka-angka. Pendekatan kualitatif merupakan suatu pendekatan dengan menggunakan data non angka atau berupa dokumendokumen manuskrip maupun pemikiranpemikiran yang ada dimana dari data tersebut kemudian dikategorikan berdasarkan relevansinya dengan pokok permasalahan yang dikaji.

Pada penelitian ini peneliti menggunakan penelitian kepustakaan (library research). Menurut M. Nazir, penelitian kepustakaan adalah teknik pengunpulan data dengan mengadakan penelaahan terhadap buku-buku, literaturliteratur, catatan-catatan, dan laporanlaporan yang ada hubungannya dengan masalah yang dipecahkan.Sumber data primer dalam hal ini adalah novel Api Tauhid karya Habiburrahman El Shirazy, diterbitkan oleh Republika 2014 akan ditelaah dan dikumpulkan melalui pencatatan, pengetikan, penyuntingan, atau alih-tulis. Sumber sekundernya adalah kumpulan berbagai literatur buku dan karya tulis lainnya yang berkaitan dengan penelitian ini.

Penelitian dengan metode kualitatif, instrumennya adalah peneliti sendiri, peranan penelitilah yang menentukan keseluruhan apa yang dirancangnya.

Analisis data dalam penelitian ini mengacu sebagaimana dikemukakan oleh Miles dan Hubermanyaitu melalui tiga tahap, antara lain: reduksi data, penyajian data, dan penarikan kesimpulan. Pada tahap pertama, ketika data sudah terkumpul melalui metode baca dan catat, data-data tersebut kemudian diolah melalui penggolongan data-data mana yang tergolong nilai akidah, ibadah, ataukah akhlak., 
membuang yang tidak perlu, dan pengorganisasian data.Tahap kedua, data disajikan dalam bentuk narasi beserta penafsiran di dalamnya, dan berlanjut pada tahap ketiga yaitu penarikan kesimpulan.

Dalam penelitian ini peneliti memilih teknik validasi data dengan cara meningkatkan ketekunan yaitu dengan cara pengamatan yang cermat dan berkesinambungan sebagai wujud dari peningkatan ketekunan yang dilakukan oleh peneliti. Ini dimaksudkan guna meningkatkan kredibilitas data yang diperoleh. Dengan demikian, peneliti dapat mendeskripsikan data yang akurat dan sistematis tentang apa yang diamati.

\section{HASIL PENELITIAN DAN PEMBAHASAN}

Dalam penelitian ini peneliti tidak membahas nilai-nilai islami yang ada dalam keseluruhan novel, akan tetapi penelitian ini mengkaji nilai-nilai islami dari tokoh sejarah yang diceritakan dalam novel Api Tauhid karya Habiburrahman El Shirazy adalah Badiuzzaman Said Nursi, ulama terkemuka dari Turki yang lahir pada tahun 1876-1960 M.Hasil penelitian tersaji sebagaimana tabel berikut ini.

\section{Tabel Nilai-Nilai Islami dalam Novel Api Tauhid Karya Habiburrahman EI Shirazy}

\begin{tabular}{|c|c|c|}
\hline No & Nilai Islami & Kutipan \\
\hline \multirow[t]{3}{*}{1} & $\begin{array}{l}\text { Nilai Akidah : } \\
\text { a.Penanaman } \\
\text { nilai keimanan }\end{array}$ & $\begin{array}{l}\text { "Malam itu bulan terang benderang di langit. Nuriye mengajak Said } \\
\text { melihat keindahan rembulan yang mendekati purnama itu" } \\
\text { "Bulan itu bertasbih anakku. Alam semesta ini bertasbih, memuji Allah, } \\
\text { kata Nuriye. Said kecil mengangguk." } \\
\text { "Pohon-pohon juga bertasbih, ibu? "tanya Said. } \\
\text { "Iya." } \\
\text { "Batu-batu, kerikil, pasir?" } \\
\text { "Iya semua yang ada di langit dan di bumi ini bertasbih kepada Allah, } \\
\text { anakku." }\end{array}$ \\
\hline & \multirow[t]{2}{*}{$\begin{array}{l}\text { b.Iman kepada } \\
\text { Allah }\end{array}$} & $\begin{array}{l}\text { Saat mereka sedang asyik memetik sayur, tiba-tiba berembus angin yang } \\
\text { kencang. Angin itu berpusar dengan ganas. Sang ibu sangat cemas, ia } \\
\text { menyuruhanak-anaknya menyela- } \\
\text { matkan diri berlindung di balik batu besar. } \\
\text { "Hanya Said yang tidak cemas. Dengan tenang ia berkata kepada ibunya, } \\
\text { "ibu, tak usah takut dan cemas. Allah akan menyelamatkan kita daripada } \\
\text { bahaya ini, insya Allah. }\end{array}$ \\
\hline & & $\begin{array}{l}\text { "Said Nursi merasa dirinya sangat lemah. Hanya kepada Allah tempat } \\
\text { bergantung. Terkadang ia merasa ajal sudah di depan mata. Hal itu } \\
\text { semakin membuat dirinya hanya bisa pasrah total kepada Allah. Tidak ada } \\
\text { putus asa, yang ada adalah penyerahan diri kepada Allah dengan memohon } \\
\text { kepada Allah." }\end{array}$ \\
\hline & \multirow[t]{2}{*}{$\begin{array}{l}\text { b. Iman kepada } \\
\text { Takdir Allah }\end{array}$} & $\begin{array}{l}\text { "Tunggu sebentar, jika kalian melihat kejadiannya kalian akan berpikir } \\
\text { jernih. Jika anak ini mati, maka itulah ajalnya yang menentukan } \\
\text { kematiannya adalah Allah, adapun penyebab kematian itu adalah Mustafa } \\
\text { Pasya. Sebab dialah yang dengan sengaja memberiku kuda liar dalam } \\
\text { pertandingan. }\end{array}$ \\
\hline & & $\begin{array}{l}\text { "Saya sama sekali tidak takut. Bahkan jika akibatnya saya harus dibunuh } \\
\text { dan dibuang di laut, maka laut akan jadi kuburan saya yang luas. Jika saya } \\
\text { dieksekusi, maka saya akan bersemayam di jantung setiap rakyat negeri } \\
\text { ini. Ketika saya datang ke Istanbul ini, saya sudah merelakan diri saya } \\
\text { sebagai tumbal untuk memperjuangkan nasib bangsa saya!" }\end{array}$ \\
\hline
\end{tabular}




\begin{tabular}{|c|c|c|}
\hline & & $\begin{array}{l}\text { "Dalam karyanya Said Nursi melampirkan penjelasan bahwa iman kepada } \\
\text { hari akhir adalah kebenaran iman yang bahkan seorang jenius ahli filsafat } \\
\text { selevel Ibnu Sina telah mengakui ketidakberdayaannya di hadapan } \\
\text { kebenaran iman tersebut. Ibnu Sina mengatakan: "Kebangkitan kembali di } \\
\text { hari kiamat tidak dapat dipahami dengan kriteria rasional!" }\end{array}$ \\
\hline \multirow[t]{9}{*}{2} & $\begin{array}{l}\text { Nilai Ibadah : } \\
\text { a.Shalat tepat } \\
\text { waktu }\end{array}$ & $\begin{array}{l}\text { "Dia pernah mengajak kalian sesuatu?" } \\
\text { "Pernah." } \\
\text { "Apa itu?" } \\
\text { "Shalat berjama'ah, jika datang waktu salat dia mengajak kami salat } \\
\text { berjama’ah. Dia menjadi imam dan kami menjadi ma'mum.”. }\end{array}$ \\
\hline & $\begin{array}{l}\text { b.Menjaga diri } \\
\text { dari perbuatan } \\
\text { maksiat }\end{array}$ & $\begin{array}{l}\text { "Saya hendak berbuat baik membersihkan dan merapikan kamarnya. Tiba- } \\
\text { tiba dia marah dan mengusir saya agar keluar dari kamarnya. Dia lalu } \\
\text { menutup kamarnya dengan keras! Seolah-olah ini rumahnya. Aku tak } \\
\text { dianggapnya sama sekali!" } \\
\text { "Omar Pasya menghela nafas lega." "Hanya itu?" "Saya juga tersinggung } \\
\text { dengan sikapnya yang lain." "Apa itu?" } \\
\text { "Selama dia ada di rumah ini. Dia sama sekali tidak mau memandang } \\
\text { wajah kami. tidak sekalipun mau mengangkat mukanya memandang wajah } \\
\text { kami. terlalu so"mbong anak muda itu! Kelakuannya aneh!" }\end{array}$ \\
\hline & c.Berdzikir & $\begin{array}{l}\text { "Sepanjang jalan, dia berdzikir. Jika dia mengajak bicara kepada kami, } \\
\text { selalu saja di balik yang ia bicarakan ada hikmah yang menyentuh hati. } \\
\text { Kami jadi tahu tujuan kami semestinya dalam hidup ini. Dia masih muda, } \\
\text { tapi ilmunya adalah kedalaman ilmu ulama yang tidak muda." }\end{array}$ \\
\hline & d.Shalawat & $\begin{array}{l}\text { "Badiuzzaman Said Nursi larut dalam kerinduan kepada Rasulullah. } \\
\text { Dirinya seperti lebur dalam harunya salawat untuk Rasulullah. Malam itu } \\
\text { malam jumat. Wirid utama Badiuzzaman seperti ulama-ulama lainnya } \\
\text { adalah memabukkan diri dalam tegukan nikmat salawat. }\end{array}$ \\
\hline & \multirow[t]{5}{*}{ e.Dakwah } & $\begin{array}{l}\text { "Anak buahmu pasti sudah memberi tahu kamu. Aku datang untuk } \\
\text { mengajakmu bertaubat, kembali ke jalan yang lurus. Aku mengajakmu } \\
\text { untuk menghentikan kebiasaanmu berbuat maksiat dan berlaku lalim!" } \\
\text { "Kalau aku tidak mau?" } \\
\text { "Aku akan membunuhmu!" } \\
\text { "Kalau aku tidak mau?" } \\
\text { "Aku akan membunuhmu!". }\end{array}$ \\
\hline & & $\begin{array}{l}\text { "Ia lantas membacakan ayat Alquran dan hadis berkenaanlarangan } \\
\text { meminum arak.Kemudian mendedekati gubernur Omer Pasya," } \\
\text { "Bagaimana anda mau mengatur provinsi ini, sementara akal dan pikiran } \\
\text { anda dikuasai arak? Anda punya dua pilihan, hentikan perbuatan maksiat } \\
\text { ini atau aku bakar tempat ini!"” }\end{array}$ \\
\hline & & $\begin{array}{l}\text { "Alasan apa yang memperbolehkan seseorang mengabaikan atau berhenti } \\
\text { menjalankan kewajiban-kewajiban agama? Perbuatan seperti itu akan } \\
\text { berdampak buruk bagi agama, dan dunia. "...Sesungguhnya, meremehkan } \\
\text { penerapan ajaran agama akan mengakibatkan lemahnya umat. Dan } \\
\text { kelemahan akan mengundang musuh mengalahkan kalian...!" }\end{array}$ \\
\hline & & $\begin{array}{l}\text { "Al-Quran adalah wahyu Allah. Saya akan buktikan dan tunjukkan kepada } \\
\text { dunia bahwa al-Quran itu seperti matahari yang tidak akan padam } \\
\text { cahayanya. Al-Quran tidak akan bisa mereka musnahkan" } \\
\text { "Bagaimana cara apa ustadz melakukannya?" } \\
\text { "Dengan mendidik generasi kita secara benar. Kita perlu mendirikan lebih } \\
\text { banyak madrasah di Van. Lalu kita dirikan madrasah baru di Bitlis, di } \\
\text { Siirt, di Diyarbakir dan di seluruh Anatolia Timur ini. Di madrasah itu, } \\
\text { kita ajarkan al-Quran dan diiringi ilmu modern. Dengan cara itu anak-anak } \\
\text { muda kita akan memahami isi al-Quran, mencintai al-Quran dan tidak } \\
\text { akan melupakan al-Quran. Kita beri penghargaan bagi para penghafal } \\
\text { alQuran.". }\end{array}$ \\
\hline & & "Karena kebangkitan kembali dan berkumpulnya manusia di Padang \\
\hline
\end{tabular}




\begin{tabular}{|c|c|c|}
\hline & & $\begin{array}{l}\text { Mahsyar terjadi melalui perwujudan asma Allah yang paling besar, itu } \\
\text { harus dibuktikan dengan semudah musim semi, diterima dengan kepastian } \\
\text { dan diimani dengan kuat." } \\
\text { Musim semi adalah bukti tak terbantahkan adanya hari kebangkitan, bagi } \\
\text { orang yang berpikir. Sangat mudah bagi Allah membangkitkan yang telah } \\
\text { mati, semudah Allah menciptakan musim semi, tumbuhan yang telah } \\
\text { sekarat dan mati di musim dingin tumbuh kembali dengan subur di musim } \\
\text { semi. Dan Allahlah yang menumbuhkannya." }\end{array}$ \\
\hline \multirow[t]{7}{*}{3} & $\begin{array}{l}\text { Nilai Akhlak } \\
\text { a.Hormatkepada } \\
\text { orang } \\
\text { tua }\end{array}$ & $\begin{array}{l}\text { "Nuriye baru saja salam dari salat dhuha, ketika Said kecil berkata } \\
\text { padanya; Ibu, aku ingin pergime-nuntut ilmu di madrasah, izinkan aku." } \\
\text { Nuriye tersenyum mende- } \\
\text { ngar kata-kata Said. "Kau masih terlalu kecil, Said, tunggulah sampai kau } \\
\text { lebih besar, "ujar Nuriye penuh sayang. } \\
\text { "Tapi aku tidak sabar untuk belajar al-Quran lebih dalam lagi. Aku sudah } \\
\text { bisa membacanya, aku ingin lebih dari itu, bu. Aku ingin tahu isi al-Quran, } \\
\text { "desak Said kecil." "Said adalah anak yang sangat taat pada ibunya. Maka } \\
\text { Said pun menjawab; "Baiklah ibu, mungkin itu yang terbaik." Maka setiap } \\
\text { kali Abdullah pulang, }\end{array}$ \\
\hline & \multirow[t]{2}{*}{$\begin{array}{l}\text { b.Hormat kepada } \\
\text { ahli ilmu }\end{array}$} & $\begin{array}{l}\text { "Saya membaca sungguh-sungguh dan memahaminya, Syaikh, "tegas Said } \\
\text { Nursi. "Dengan siapakah kamu minta penjelasan? "tanya Syaikh } \\
\text { Muhammad Celali lagi." "saya baca sendiri, dan saya pahami sendiri. } \\
\text { Hanya kepada Allah saya bergantung, "jawab Said Nursi". "Kamu perlu } \\
\text { bimbingan pelajar yang lebih tua, "kata Syaikh Muhammad Celali." } \\
\text { "Badiuzzaman Said Nursi menarik nafas panjang lantas kata; "Syaikh, } \\
\text { kitab-kitab itu ibarat peti harta karun. Kuncinya ada pada Syaikh. Saya } \\
\text { datang untuk mendapatkan kunci itu dari Syaikh, bukan dari yang lain." }\end{array}$ \\
\hline & & $\begin{array}{l}\text { "Sejak itu, tidak sedikit murid-murid di madrasah itu yang meminta Said } \\
\text { ikut mengajar. Namun demi hormatnya kepada gurunya, Said tidak } \\
\text { memenuhi permintaan itu. Namun para murid di situ tetap mendesak Said } \\
\text { Nursi. Akhirnya Said Nursi setuju untuk mengajari para murid dan } \\
\text { berkata;"dengan sarat, saya hanya mengajar kalian ilmu-ilmu terkait } \\
\text { bahasa Arab saja. Ada pun ilmu-ilmu agama tidak, kalian harus belajar } \\
\text { pada Syaikh Muhammad Emin Efendi. Sebab beliau adalah guru saya." } \\
\text { "Dan tentu, terlebih dahulu Said Nursi meminta izin kepada gurunya dan } \\
\text { diizinkan." }\end{array}$ \\
\hline & $\begin{array}{l}\text { c.Hormat kepada } \\
\text { pemerintah }\end{array}$ & $\begin{array}{l}\text { "Said Nursi pun patuh terhadap perintah gubernur, dengan penuh sukarela } \\
\text { ia tinggalkan Bitlis dan ribuan jamaahnya. Sebab, tujuan dia memberikan } \\
\text { pengajaran di Masjid Qurasyi itu tidak menyai- } \\
\text { ingi atau pun menandingi gurunya } \\
\text { Ia hanya ingin kehormatan dirinya diperlakukan dengan adil." }\end{array}$ \\
\hline & d.Rendah diri & $\begin{array}{l}\text { "Kenapa orang-orang terus menggunjingkan masalah itu, dan begitu cepat } \\
\text { berita bohong itu menyebar ke mana-mana?" Salah seorang murid } \\
\text { sekaligus pendukungnya bertanya pada Badiuzzaman Said Nursi." } \\
\text { "Dengan penuh kerendahan diri dan melihat diri, Said Nursi menjawab; } \\
\text { "Tetap saja yang salah sesungguhnya diriku, dan aku telah dihukum } \\
\text { dengan dua hukuman sekaligus atas kesalahanku. Pertama, teguran dari } \\
\text { Allah. Dan kedua, celaan orang banyak kepadaku. Sebab utama aku } \\
\text { sampai terlambat salat subuh di masjid adalah karena aku lalai tidak } \\
\text { membaca wirid malam yang biasanya aku baca setiap malam." }\end{array}$ \\
\hline & e.Sopan santun & $\begin{array}{l}\text { "Darvis Vahdeti Bey, Saudaraku!" } \\
\text { "Penulis harus memiliki sopan santun. Dan sopan santun mereka harus } \\
\text { dibentuk oleh sopan santun Islam. Hukum pers harus dibentuk oleh sopan } \\
\text { santun gamis dari nurani. Karena reformasi Islam telah menunjukkan } \\
\text { bahwa yang mengatur hati nurani adalah semangat Islam, cahaya di atas } \\
\text { cahaya" }\end{array}$ \\
\hline & f.Jujur & $\begin{array}{l}\text { "Seumur hidup. Saya tidak pernah berkata bohong. Alhamdulillah. Apa } \\
\text { yang saya katakan itu adalah benar. Apakah tuan hakim mengira saya takut }\end{array}$ \\
\hline
\end{tabular}




\begin{tabular}{|l|l|l|}
\hline & $\begin{array}{l}\text { dengan pengadilan ini? Tidak sama sekali, saya tidak takut. Saya hanya } \\
\text { takut pada pengadilan akhirat." }\end{array}$ \\
\hline \multirow{2}{*}{ g.Suka damai } & $\begin{array}{l}\text { "Saya umat Nabi Muhammad Saw. Saya menjadikan Al-Qur'an sebagai } \\
\text { pedoman hidup. Saya menilai segala masalah berdasar- } \\
\text { kan aturan Islam. Saya menolak hal-hal yang bertentangan dengan niali- } \\
\text { nilai Islam. Melakukan keru- } \\
\text { Suhan dengan merusak harta oranglain, membunuh yang tidak } \\
\text { bersalah, membuat keonaran yang mengganggu kepentingan umum adalah } \\
\text { bertentangan dengan nilai-nilai Islam." }\end{array}$ \\
\hline
\end{tabular}

\section{SIMPULAN DAN SARAN}

Hasil penelitian novel Api Tauhid karya Habiburrahman ElShirazy mengandung nilai-nilai islami yang bisa kita petik sebagai berikut : 1) Nilai-nilai akidah yang meliputi penanaman nilai keimanan, iman kepada Allah, iman kepada takdir Allah, dan iman kepada hari akhir, 2)Nilai-nilai ibadah yang meliputi; shalat tepat waktu, menjaga diri dari perbuatan maksiat, berdzikir, shalawat, dan berdakwah, 3)Nilai-nilai akhlak yang meliputi hormat kepada orang tua, hormat kepada ahli ilmu, hormat kepada pemerintah, rendah diri, sopan santun, jujur dan suka damai.

Berdasarkan hasil kajian analisis nilai-nilai islami yang terkandung dalam novel Api Tauhid karya Habiburrahman ElShirazy , peneliti menyampaikan beberapa saran sebagai berikut : 1)Novel Api Tauhid sarat akan nilai-nilai islami yang bisa kita petik oleh sebab itu selayaknya ini menjadi bahan bacaan yang menarik. 2) Penelitian terhadap novel Api Tauhid perlu dilakukan dan dilanjutkan oleh peneliti yang berminat karena ada banyak hal yang dapat dikaji dan diteliti dari novel tersebut, baik dari disiplin ilmu dan pendekatan yang digunakan maupundikaji dari aspek lainnya.

\section{DAFTAR RUJUKAN}

Damono, Sapardi Djoko. 1979. Sosiologi Sastra:Sebuah Pengantar Singkat. Jakarta: PusatPembinaan dan
Pengembangan Bahasa dan Ilmu Sastra.

El Shirazy, Habiburrahman. 2014. Api Tauhid.Jakarta:Republika.

Endraswara. 2011.Metodologi Penelitian Sastra,Epistemologi, Model,Teori, dan Aplikasi. Yogyakarta: CAPS.

Nasrun, Haroen. 2000. Fiqih Muamalah. Jakarta: Gaya Media Pratama.

Nata, Abudin. 2000. Akhlak Tasawuf. Jakarta:Raja Grafindo.

Nazir, M. 2005. Metode Penelitian, Jakarta, Ghalia Indonesia.

Nugroho, Doni. 2010. Nilai-nilai Islam dalam novel The Half Mask karya Deasylawati Prasetyaningtyas : Tinjauan Sosiologi Sastra. (Online) http://eprints.ums.ac.id/8508/1/A31 0060288.pdf, 25-5-2017).

Nurgiantoro, Burhan. 2010. Teori Pengkajian Sastra.Yogyakarta: Gadjah Mada University Press

Pasha, Mustofa Kamal. 2003. Akidah Islam. Jogjakarta: Citra Karsa Mandiri.

Permadi,K. 2001. Iman dan Taqwa menurut Al Qur"an, Jakarta: Rineka Cipta.

Purba. 2010. Sastra Indonesia Kontemporer. Yogyakarta: Graha Ilmu. 


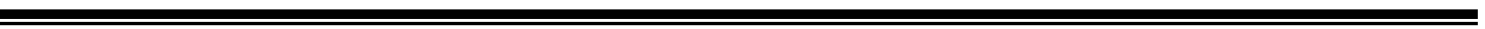

